\title{
Histological characterization of cellular types during Scinax fuscovarius oogenesis (Lutz) (Anura, Hylidae)
}

\author{
Classius de Oliveira \& Lia Raquel de Souza Santos
}

Departamento de Biologia, Universidade Estadual Paulista. 15054-000 São José do Rio Preto, São Paulo, Brasil. E-mail: classius@bio.ibilce.unesp.br

\begin{abstract}
This paper describes morphological characteristics of the ovarian germinative cells of the Scinax fuscovarius (Lutz,1925). The ovary is organized in primordial germinative cells (oogonia) and follicular structures (ovarian follicle) - oocytes surrounded by follicular cells. Oogonia: their nests are peripherically localized, containing cells with large and oval nucleus. Oocytes I: basophilic cytoplasm; the spherical nucleus presents few nucleoli, one or two; the follicular cells (one tenuous layer) surround these previtellogenic cells. Oocytes II: the cell is larger and the cytoplasm becomes more basophilic; the nucleus presents few nucleoli and contains many chromosomes in the periphery (beginning the perinucleolar stage). Oocytes III: the cytoplasm acquires an intense acidophilia; the peripherical region of cytoplasm is filled with yolk and the internal region has no yolk at all; pigment synthesis begins; the follicular envelope presents three tenuous layers: an inner acellular (vitelline envelope) and two cellular layers (follicle cells). Oocytes IV: a characteristic of this stage is the differentiation between the animal and the vegetal poles; the nucleus in the animal hemisphere and the pigments give the oocyte a color dark brown; the vitellogenesis is intense and the yolk occupies the whole cytoplasm.
\end{abstract}

KEY WORDS. Oocytes, oogonia, ovary, pigment, vitellogenesis.

RESUMO. O estudo apresenta algumas características histológicas das células germinativas ovarianas de Scinax fuscovarius (Lutz, 1925) após análise com colorações pelo H/E e Tricrômico de Mallory. O ovário apresenta as células germinativas primordiais, as ovogônias, as quais passam por uma citodiferenciação e, juntamente com células somáticas associadas, constitui estruturas foliculares, os folículos ovarianos, que são os ovócitos envolvidos por células foliculares. Ovogônias: formam ninhos perifericamente localizados, contendo células com núcleo grande e oval associadas com uma única célula folicular. Ovócitos I: o citoplasma é discretamente basófilo; seu núcleo é esférico e apresenta poucos nucléolos, geralmente se observa um ou dois; as células foliculares se apresentam em uma camada (epitélio pavimentoso simples) que circunda a célula germinativa em estado prévitelogênico. Ovócitos II: a célula é maior que a anterior e o citoplasma torna-se mais basófilo; o núcleo apresenta raros nucléolos na periferia e muitos cromossomos constituindo arranjos irregulares, é quando se inicia o estádio perinucleolar. Ovócitos III: o citoplasma adquire intensa acidofilia; a região periférica do citoplasma é preenchida por inclusões vitelínicas que ainda não ocorrem na região interna; inicia-se a síntese de pigmentos; o envoltório folicular apresenta três camadas: uma interna acelular (envoltório vitelínico) e duas camadas de células foliculares. Ovócitos IV: uma característica deste estádio é a diferenciação entre o pólo animal e o vegetal; o núcleo ou vesícula germinativa se desloca para o hemisfério animal e os pigmentos conferem uma cor marrom escura; a vitelogênese é intensa e o vitelo ocupa todo o citoplasma.

PALAVRAS CHAVE. Ovário, ovócito, ovogônia, pigmento, vitelogênese.

Although some studies report general descriptions on the morphological organization of the ovary in anurans (CosTA et al. 1998, Cabada et al. 1996, Roca \& Echeverría 1996, Duellman \& Trueb 1994, Hermosilla et al. 1986, Pancharatna \& Saidapur 1985, Rastogi et al. 1983, Nina \& Del Pino 1977, LofTs 1974, Dumont 1972), the information on this issue is scarce for species of the Hylidae family (Oliveira \& Andrade 1999, Del Pino 1989, Del Pino et al. 1986). The gross structural reproductive system of the $S$. fuscovarius were analyzed and described for the ovary and fat bodies (Oliveira \& Andrade 1999) and oviduct (Oliveira \& Andrade 1997). However, the inner morphological characteristics of the majority of these animals, especially those inhabiting the neotropical regions, are not completely known. This paper aims at describing some histological characteristics of the ovarian germinative cell types of $S$. fuscovarius.

Revista Brasileira de Zoologia 21 (4): 919-923, dezembro 2004 

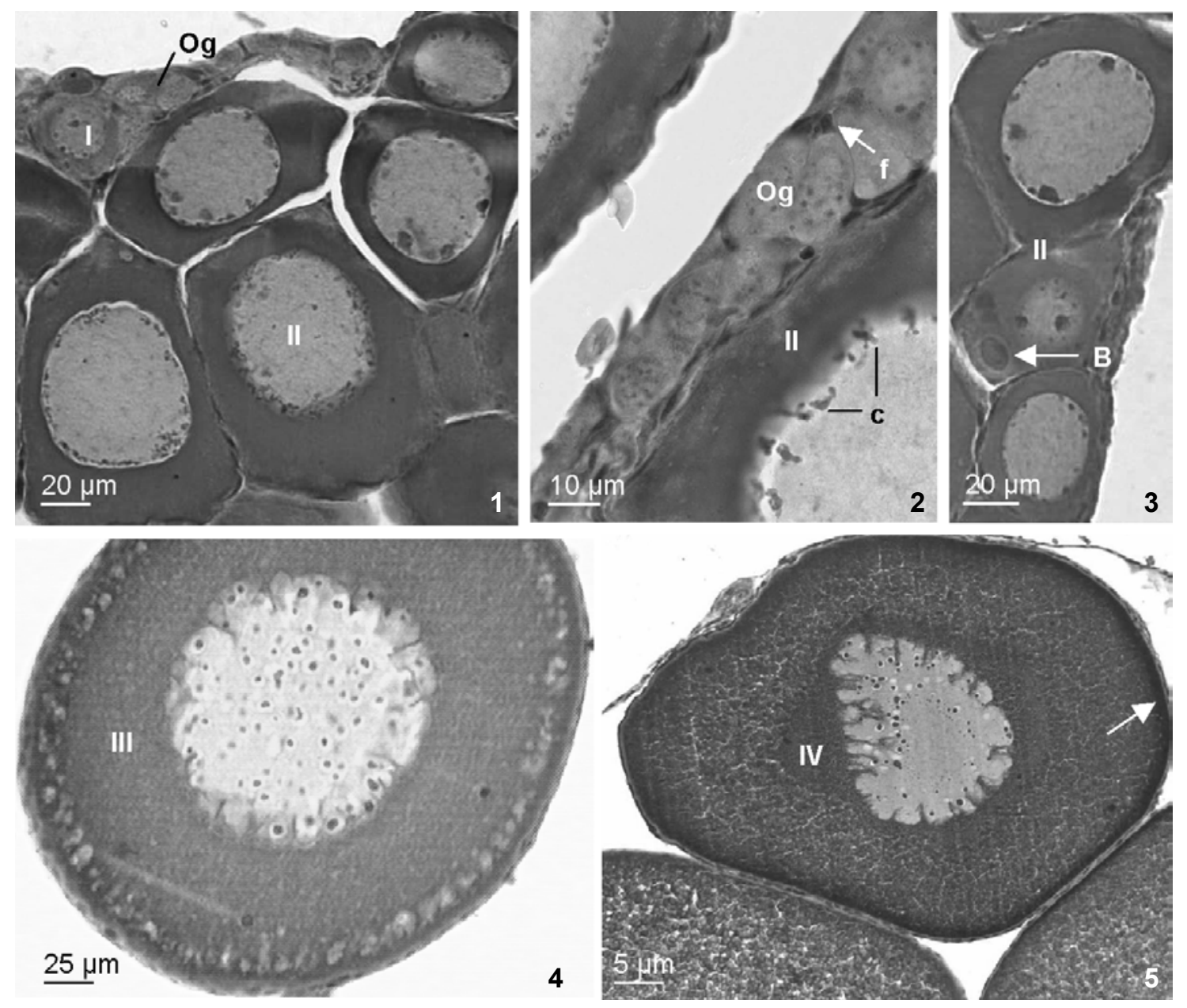

Figures 1-5. Ovarian germinative cells of the S. fuscovarius (H/E); (1-3) NEST of oogonia $(\mathrm{Og})$ with associated follicular cells ( $f$ ) and oocytes I and II with peripherically condensed chromosomes (C). In the cytoplasm of oocyte II the yolk nucleus or Balbiani body (B) can be identified; (4-5) oocytes III and IV with central nucleus showing numerous nucleoli distributed throughout the nucleoplasm. In the animal hemisphere of the oocytes IV the pigmentation is intense (arrow). A large number of yolk granules and globules can be noticed in this phase.

\section{MATERIAL AND METHODS}

Five adult females of $S$. fuscovarius (Amphibia, Anura, Hylidae) were collected in the Research Sector in Nourishment of Aquatic Organisms at UNESP $\left(22^{\circ} 59^{\prime} \mathrm{S}, 48^{\circ} 25^{\prime} \mathrm{W}\right.$, Botucatu, São Paulo State, Brazil). The animals were obtained at the time of reproductive activity of the species, through night incursions from of October to December, 1992 (one exemplar in October, two in November and two in December). As soon as they were captured, the individuals were anesthetized with ether, sacrificed and sent to the morphological analysis.

The animals were dissected through median incision and the reproductive system organs were exposed to the dropping of the Bouin solution "in situ". From these animals, small fragments of the ovaries from the middle region $\left(0,5 \mathrm{~cm}^{2}\right)$ were fixed in Bouin ( $20 \mathrm{~h}$ ), washed and transferred to a $70 \%$ alcohol solution. The material was sent to go through the histological routine (Ribeiro \& Lima 2000) for dehydration, clarification, and embedded in paraffin. From this material, slits of $6 \mu \mathrm{m}$ were obtained to subsequent coloration with $\mathrm{H} / \mathrm{E}$ and Trichromic of Mallory, analysis of the structures, and documentation in light microscopy (Zeiss-Jenaval).

The specimen used were fixed in $10 \%$ neutral formalin and preserved for other descriptions and as proof material. Three samples were placed in the Herpetological Collection of the Department of Zoology, IBILCE/UNESP-SJRP (5966, 5967 and 5968). 

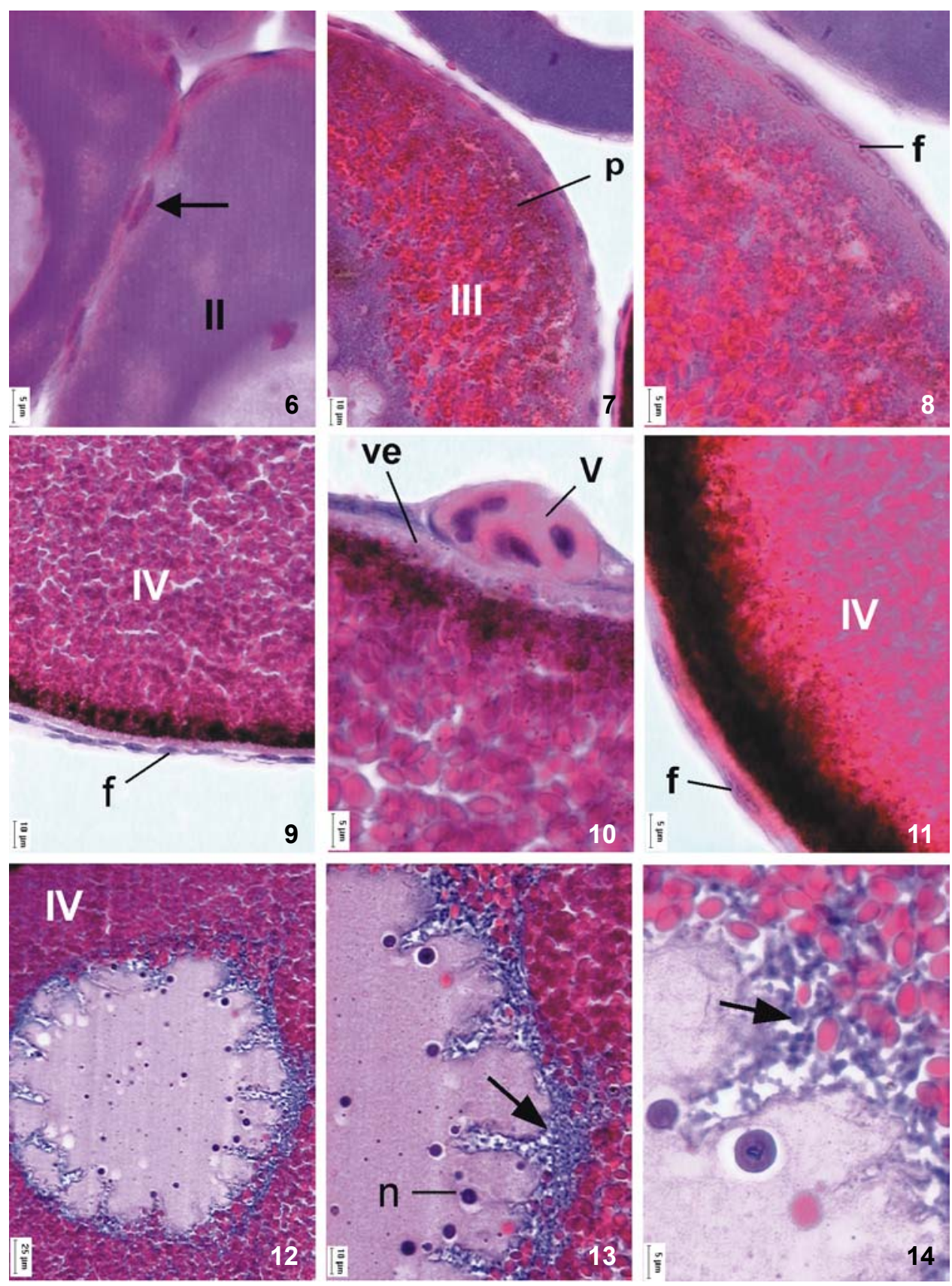

Figures 6-14. Ovarian germinative cells of the S. fuscovarius (Tricromic of Mallory): (6) oocytes II with associated follicular cells still flat (arrow), the cytoplasm is strongly basophilic and homogenously granular; (7-8) later oocyte III with accumulation of yolk and the pigments ( $p$ ) are uniformly distributed; (9-11) the follicular envelope of the oocyte IV presents the follicle layers ( $f$ ) and vitelline envelope (ve). The outer follicular layer presents blood vessels (v). The pigments give the oocyte a color dark brown and the yolk occupies the whole cytoplasm; $(12,-14)$ the contour of the nucleus is irregular and presents prominent nucleoli (n) of different sizes. The perinuclear cytoplasm (arrow) with projections into the nucleus presents granular material. Some large nucleoli containing vacuolated areas remain near the highly folded nuclear envelope. 


\section{RESULTS AND DISCUSSION}

The S. fuscovarius ovaries are lobulated organs covered with a tenuous and transparent ovarian capsule. In the ovaries there are different types of germ cells. The fat bodies are structures constituted of digitiform prolongations joined to the cranial edges of the gonad. Both structures, ovaries and fat bodies, were anatomically described and present great morphological changes during their reproductive cycle (Oliveira \& Andrade 1997). In addition, the gonad is composed of primordial germinative cells, oogonia, and follicular structures (ovarian follicle) - oocytes in different phases of maturation surrounded by layers of follicular cells. As previously described (OliveIRA \& ANDRADE 1997), among these ovarian follicles there is a scarce loose connective tissue responsible for the sacular aspect of the organ.

The morphological analysis of the germinative lineage revealed distinct cell types: Oogonia, Oocytes I, II, III and IV. The oogonia are arranged in nests peripherically localized in the ovary (Figs 1 and 2). These cells contain a scarce cytoplasm and a large and oval nucleus with uniformly distributed chromatin (Fig. 2). When compared to the oogonia a substantial increase of the cellular volume is detected in oocyte I (Fig. 1). Its cytoplasm is basophilic and exhibits 1-2 nucleoli. The oocytes II (Figs 2 and 3) is larger and its cytoplasm becomes strongly basophilic and seems to be homogenously granular. The nucleus presents few nucleoli and contains many chromosomes in the periphery (beginning the perinucleolar stage). The denomination perinucleolar stage can be used even though it is more appropriate for teleost fishes (NARAHARA 1991). Also in the cytoplasm of the oocytes II, it can be identified an acidophilic juxtanuclear mass, which is referred to as the yolk nucleus or Balbiani body (Fig. 3). Generally, one layer of follicular cells still flat surrounds these previtellogenic cells as well as those at later stages (Fig. 6). In the oocytes III (Figs 4 and 7) the cytoplasm acquires an intense acidophilia and distinct cytoplasmatic zones are recognized: the peripherical and internal cytoplasm. The peripherical region is filled with yolk and the internal one has no yolk at all (centripetal deposition). The pigment synthesis begins in this phase (Fig. 7). The contour of the nucleus is more irregular and nucleolus continues to increase in number. The follicular envelope presents three layers: an inner acellular (vitelline envelope) (Fig. 10), and two layers of the flattened follicle cells (Figs 8 and 9). The distinguishing morphological feature of the oocytes IV is the differentiation between the animal and the vegetal poles (Fig. 5). The nucleus becomes displaced towards the animal hemisphere and the pigments are deposited in the peripheral cytoplasm giving it a dark brown color. The vitellogenesis is intense and the yolk progressively occupies all of the external cytoplasm, mainly in the vegetal pole that remains filled with yolk (Figs 9, 10 and 11). Some large nucleoli containing dense spherical and vacuolated areas remain near the highly folded nuclear envelope (Figs 12, 13 and 14).
The histological characteristics observed in S. fuscovarius present similar patterns to other anurans (COSTA et al. 1998, Cabada et al. 1996, Roca \& Echeverría 1996, Hermosilla et al. 1986, Pancharatna \& Saidapur 1985, Rastogi et al. 1983, Lofts 1974). No apparent differences between the left and right ovaries were observed and the germinative cells were classified in five stages based on their structural (size and appearance of the oocytes) and histological characteristics. These features are similar to the ones found in other species: Melanophryniscus stelzneri (ROCA \& ECHEVERRÍA 1996); Eleutherodactylus unistrigatus (Nina \& Del Pino 1977) and Xenopus laevis (Dumont 1972). Each oocyte is encapsulated by the vitelline envelope and flattened follicle cells. These layers are analogous and were described to Bufo arenarum (CABADA et al. 1996) and Xenopus laevis (DumONT 1972). The vitellogenesis is intense and the yolk progressively occupies all of the cytoplasm. The oocyte and its nuclear undergo a remarkable increase in diameters during the follicular development, especially in the first and early second growth phase oocytes. This linear relation between the follicle and its nuclear diameters was described in Rana cyanophlyctis (Pancharatna \& Saidapur 1985). The amphibians have a great variability of modes of oogenesis (Duellman \& Trueb 1994, Del Pino 1989, Horton \& Tyler 1982). However, the general histological characteristics in $S$. fuscovarius present the same basic patterns to the majority of the Hylidae family.

\section{ACKNOWLEDGEMENTS}

This work was partially supported by FAPESP $\left(\mathrm{n}^{\circ}\right.$ 02/ 08016-9). The author thanks Gisele Manganelli Fernandes (Department de Letras Modernas, IBILCE) for reviewing the English version and Maria Tercília Vilela de Azeredo Oliveira and Rejane Maira Góes (Department de Biologia, IBILCE) for their invaluable suggestions.

\section{REFERENCES}

Cabada, M.O.; A.N. Sánches Riera; H.D. Genta; S.S. Sánches \& G.A. BARISONE. 1996. Vitelline envelope formation during oogenesis in Bufo arenarum. Biocell, Mendoza, 20 (1): 77 86.

Costa, C.L.S.; S.L. Lima; D.R. Andrade \& C.A. Agostinho. 1998. Caracterização morfológica dos estágios de desenvolvimento do aparelho reprodutor feminino da rã-touro, Rana catesbeiana, no sistema anfigranja de criação intensiva. Revista Brasileira de Zootecnia, Viçosa, 27 (4): 642-650.

Del Pino, E.M. 1989. Modifications of oogenesis and development in marsupial frogs. Development, Cambridge, 107 (2): 169-187.

Del Pino, E.M.; H. Steinbeisser; A. Hofmann; C. Dreyer; M. Campos \& M.F. Trendelenburg. 1986. Oogenesis in the eggbrooding frog Gastrotheca riobambae produces larges oocytes with fewer nucleoli and low RNA content in comparison to Xenopus laevis. Differentiation, London, 32: 24-33. 
Duellman, W.E. \& L. Trueb. 1994. Biology of amphibians. New York, McGraw-Hill, 670p.

Dumont, J.N. 1972. Oogenesis in Xenopus laevis (Daudin). I. Stages of oocyte development in laboratory maintained animals. Journal of Morphology, New York, 136: 153-179.

Hermosilla, I.B.; L.S. Coloma; G.H. Weigertt; E.T. Reyes \& V.O. Gomez. 1986. Caracterizacion del ovario de la "rana Chilena" Caudiverbera caudiverbera (Linne, 1758) (Anura, Leptodactylidae). Boletin de la Sociedad de Biologia de Concepción, Concepción, 57: 37-47.

Horton, P. \& M.J. Tyler. 1982. The female reproductive system of the Australian gastric brooding frog Rheobatrachus silus (Anura: Leptodactylidade). Australian Journal of Zoology, Collingwood, 30: 857-863.

LofTs, B. 1974. Reproduction, p.107-218. In: B. Lofts (Ed). Physiology of the amphibians. New York, Academic Press, 592p.

NARAHARA, M.Y. 1991. Histofisiologia do ovário de teleósteo, p. 39-46. In: Anais da semana sobre histologia de peixes da UNESP. Jaboticabal.

Nina, L.H. \& E.M.V. Del Pino. 1977. Estructura histologica del ovario del sapo Eleutherodactylus unistrigatus y observaciones sobre el desarrollo embrionario. Revista de la Pontificia Universidad Católica del Ecuador, Quito, 5 (16): 31-41.

Oliveira, C. \& U.J.A. Andrade. 1997. Anatomia dos ovários e corpos adiposos de Scinax fuscovaria (Anura, Hylidae). Acta Biologica Leopoldensia, São Leopoldo, 19 (2): 173-183. . 1999. Considerações estruturais sobre o oviduto do anuro Scinax fuscovarius (Amphibia, Hylidae). Naturalia, Rio Claro, 24: 229-238.

Pancharatna, M. \& S.K. Saidapur. 1985. Ovarian cycle in the frog Rana cyanophlyctis: a quantitative study of follicular kinetics in relation to body mass, oviduct and fat body cycles. Journal of Morphology, New York, 186 (2): 135147.

Rastogi, R.K.; I. Izzo-Vitiello \& M. Di Meglio. 1983. Ovarian activity and reproduction in the frog, Rana esculenta. Journal of Zoology, London, 200: 233-247.

Ribeiro, M.G. \& S.R. LimA. 2000. Iniciação às técnicas de preparação de material para estudo e pesquisa em morfologia. Belo Horizonte, Segrac Editora, 89p.

Roca, M.F. \& D.D. Echeverría. 1996. Morphología de los oocitos en diplotene de Melanophryniscus stelzneri (Weyenbergh, 1875) (Anura, Bufonidae). Alytes, Paris, 14 (2): 85-100.

Recebido em 14.I.2004; aceito em 12.XI.2004. 